\title{
COMPETITIVENESS ANALYSIS ON VIETNAM TOURISM IN RELATION WITH ASEAN COUNTRIES AT PRESENT
}

\author{
Vu Chien Thang* \\ Research Management and International Cooperation, Institute for Tourism Development Research,
} 58 Kim Ma, Ba Dinh, Ha Noi, Viet Nam

Received 19 April 2019

Revised 21 May 2019; Accepted 30 May 2019

\begin{abstract}
This paper aims at analyzing aspects that are affecting the competitiveness of Vietnam tourism in relation with other Southeast Asian (ASEAN) countries. The issues to be addressed are as follows: (1) the international tourist market share of Vietnam in ASEAN; (2) Vietnam's position in competitiveness ranking by the World Economic Forum (WEF); (3) Effectiveness of tourism in Vietnam in relation to ASEAN countries.
\end{abstract}

Keywords: ASEAN tourism, Vietnam Tourism, competitiveness

\section{Introduction}

It is a positive outlook of GDP's growth in Southeast Asia during 2018-2022 that shows the countries' average growth rate of $5.2 \%{ }^{2}$ As a result of the establishment of the ASEAN Economic Community, the contribution of tourism to their national income has increased. Statistic shows that Japan, Korea and China are the top source markets (ADB, 2017, p. 69). Tourism has created many jobs and become a driving force for the economic development of ASEAN countries. According to the WEF's Travel and Tourism Competitiveness Report, most ASEAN countries are ranked over the $50^{\text {th }}$ out of more than 130 countries surveyed,

\footnotetext{
Tel.: 84-988759957

Mail: phaptanhnt@gmail.com

1 The cut-off date is 31 October 2017. ASEAN growth rates are the weighted averages of those of the individual economies. Source: OECD Development Centre, MPF-2018 (Medium-term Projection Framework). For more information on the MPF, please see www.oecd.org/dev/asia-pacific/mpf.htm.
}

which reflects that the regional countries focus on tourism development.

One of the strengths of the region's destinations is their reasonable tour prices. According to the cost of living index, ${ }^{3}$ the most affordable ASEAN destinations in the world are led by Cambodia, Indonesia and Vietnam. In addition, the region benefits from having top hotels at competitive prices in China, Indonesia and Malaysia for less than $100 \mathrm{USD} /$ night. This price competitiveness is quite impressive in comparison with such high-income neighboring destinations as Japan, Singapore, and South Korea. However, many ASEAN countries are facing gaps in infrastructure development, including air, road and tourism facilities and ICT readiness. In addition, regional countries that encountered political instability reduced their

\footnotetext{
2 Based on Numbeo's cost-of-living index compared to New York City. This is a consumer price index, including grocery, restaurant, transportation and common supporting services.
} 
competitiveness in safety and security index (WEF, 2017, p. 15).

Since 2010, the number of international tourists has grown three-fold from 5 million to more than 15 million in 2018. Tourism industry, generated 620 trillion VND (26.75 billion USD) in total tourist revenue, up 110 billion VND (4.75 billion USD) compared to 2017. In 2018, international arrivals to Vietnam reached 15.5 million, up 2.7 million compared to 2017, while domestic tourists grew by 6.8 million compared to 2017 , to an estimated 80 million in 2018. In this paper, we assess the competitiveness of Vietnam tourism among ASEAN countries in the various aspects of World Economic Forum's competitiveness index described below in the links with comparison of international arrivals, revenue and heritage in ASEAN countries through years. Accordingly, we locate the position of Vietnam competitiveness among ASEAN countries.

\section{Literature review}

Tourism industry plays an important role in economy, employment and prosperity of countries as it offers opportunities for on-spot exports, female and youth workers, medium and small enterprises, and culture exchanges among others. In the supply side of this industry, it is notable that many tourism products, which are throughout the value chain, can be creatively formed. It has a strong effect on local economy. In the demand side, the global demand for travel and tourism is currently booming, especially in ASEAN countries. In the next decade (2018-2028), the worldwide demand for tourism is expected to increase nearly $4 \%$ annually, faster than the global economic growth (WTTC, 2018, p. 1) . $^{3}$

3 https://www.wttc.org/-/media/files/reports/ economic-impact-research/archived/regions-2018/ world2018.pdf, retrieved on 20 May 2019
Southeast Asia international tourist arrivals in 2017 reached 120.4 million (accounting for $9 \%$ of the global figure), which shows significant demand (UNWTO, 2018, p. 5), and the region's share in global demand is expected to grow by $10.3 \%$ by 2030 (or 187 million visitors) (UNWTO, 2011, p. 34).

The government of Vietnam visions tourism as a strategic and driving force of socio-economic development. The Politburo resolution No. 08-NQ/TW dated 16/1/2017 set the objectives which develop tourism into a spearhead industry and Vietnam into a leading destination in Southeast Asia, through a focus on, inter alia, (i) developing tourism infrastructure, (ii) strengthening tourism promotion, (iii) generating a favorable environment for tourism businesses, (iv) developing tourism human resources, and (v) improving State management of the tourism sector. Currently, Vietnam is developing a national tourism strategy to 2030, vision to 2050 and an action plan that guide activities and investments to achieve the 2030 targets and to drive the development of the tourism sector over the coming decades.

Vietnam, however, is not alone in this pursuit to leverage economic opportunities from tourism, and will have to contend for market share with proactive regional competitors. Eager to capitalize on the rapidly-increasing outbound travelers to the region, many countries in Southeast Asia are prioritizing tourism in their economic development agendas, setting lofty visitor number targets, and formulating sector strategies and investment plans. Thailand is finalizing its National Tourism Development Plan 2017-2021, Indonesia is preparing Integrated Tourism Master plans for the development of 10 high-priority destinations, and in the Philippines, the government 
is finalizing the new National Tourism Development Plan (NTDP 2016-2022). In this fiercely competitive environment for visitors, Vietnam will have to be strategic in focusing on the market segments where it has a competitive edge, resist the temptation to prioritize the quantity of visitors over their economic yield, and be cognizant of the implications of the pace and composition of its tourism growth for the sustainability of the sector and its impacts on the environment and natural and cultural assets (World Bank, ITDR, 2018, p. 2).

\section{Methodology}

This article is completed by the method of desk study to collect, analyze, and synthesize secondary data. Research materials, survey reports and situation reports by individuals and organizations within ASEAN countries are collected and synthesized. The data derived from biennial WEF report in 2017 were produced from 2016 data base. Likewise, the data that are collected from ASEAN secretariat were also updated in 2017. Therefore, it has a slight lateness to date, however, the figures are used as a tool to review Vietnam tourism industry's competitiveness and can be a thermometer to track our progress over time and broaden outlook for the future. In Tables 12 and 13, the avarage number is calculated based on the 3 latest consecutive years of 2014, 2015, and 2016.

\section{The international tourist market share of Vietnam in ASEAN}

In 2016, the total number of international tourist arrivals to ASEAN is 116 million. Table 1 shows that the five countries which receive less international tourist arrivals are the Philippines, Cambodia, Laos, Myanmar, and Brunei Darussalam. Vietnam ranks the $5^{\text {th }}$ among ASEAN countries, accounting for $8.62 \%$ of international tourist arrivals. The destinations that have steady growth in the region with the largest tourist market shares in 2016 are Thailand, Malaysia, Singapore, and Indonesia.

Table 1: International tourist arrivals to ASEAN nations in 2016

in comparison to it is in the region

\begin{tabular}{|l|l|c|c|}
\hline No. & \multicolumn{1}{|c|}{ Country } & Arrivals (million) & Share (\%) \\
\hline 1 & Thailand & 32.53 & 28.04 \\
\hline 2 & Malaysia & 26.76 & 22.49 \\
\hline 3 & Singapore & 16.4 & 14.14 \\
\hline 4 & Indonesia & 11.52 & 9,93 \\
\hline 5 & Vietnam & $\mathbf{1 0}$ & $\mathbf{8 . 6 2}$ \\
\hline 6 & Philippines & 5.97 & 5.15 \\
\hline 7 & Cambodia & 5.01 & 4.21 \\
\hline 8 & Laos & 4.24 & 3.66 \\
\hline 9 & Myanmar & 2.91 & 2.51 \\
\hline 10 & Brunei Darussalam & 0.22 & 0.02 \\
\hline
\end{tabular}

At present, the average growth rate of international visitors to Viet Nam is impressive with $7.15 \%$ in the period of $2007-2016$. (Figure 1) 


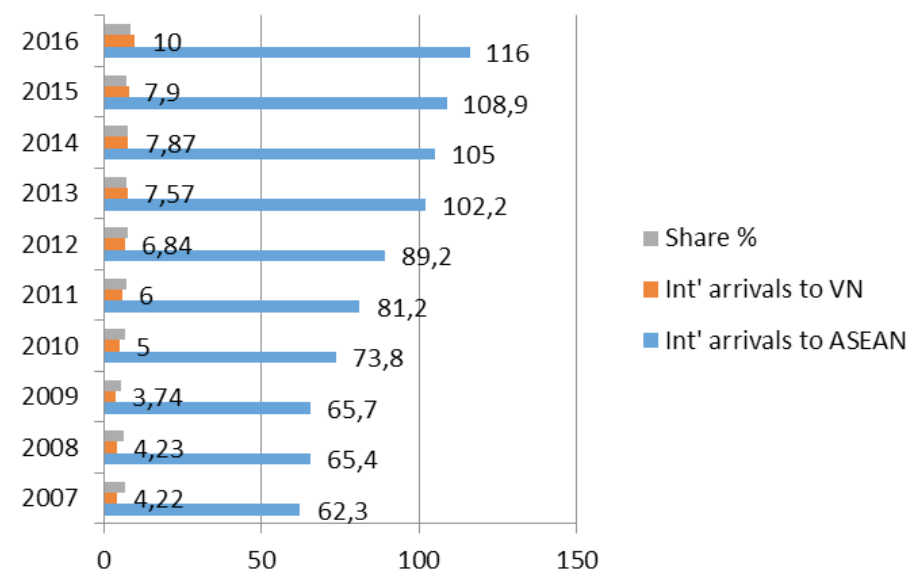

Table 2: Shares of international tourists to Vietnam in total of that to

\begin{tabular}{|c|c|}
\hline \multicolumn{2}{|c|}{ ASEAN } \\
\hline Year & Share (\%) \\
\hline 2007 & 6.77 \\
\hline 2008 & 6.47 \\
\hline 2009 & 5.69 \\
\hline 2010 & 6.78 \\
\hline 2011 & 7.39 \\
\hline 2012 & 7.67 \\
\hline 2013 & 7.41 \\
\hline 2014 & 7.50 \\
\hline 2015 & 7.25 \\
\hline 2016 & 8.62 \\
\hline
\end{tabular}

Figure 1. The share of international tourist arrivals to Vietnam in ASEAN from 2007 to 2016

5. Vietnam's position in the competitiveness ranking by the World Economic Forum (WEF)
According to WEF, the 2017 competitiveness index of Vietnam increased 8 positions, ranked at $67^{\text {th }}$ out of 136 surveyed countries (in 2016).

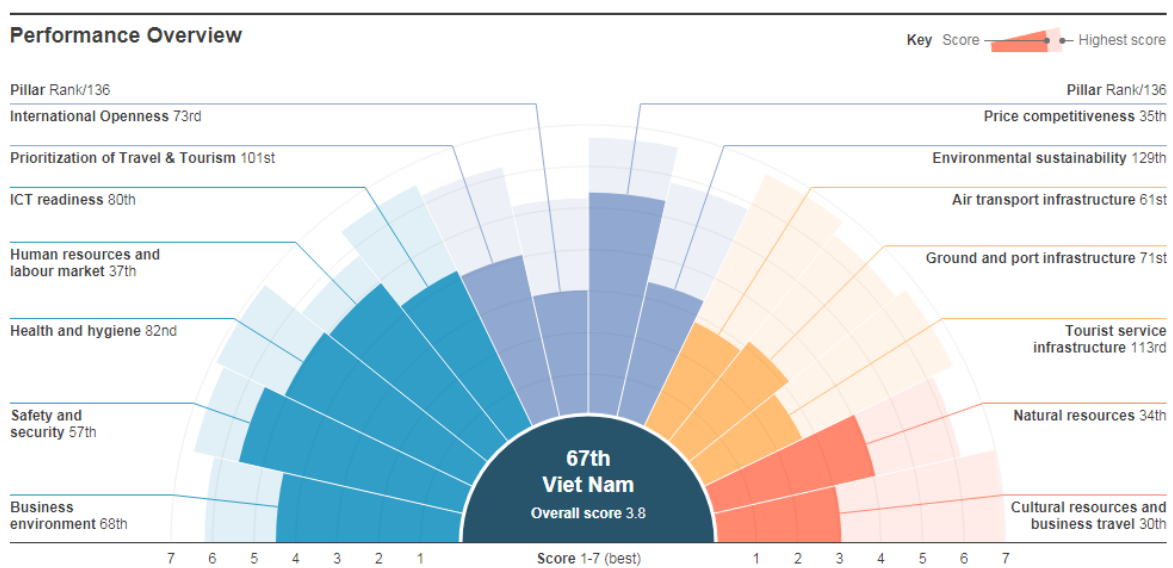

Figure 2: Overview of Vietnam tourism competitiveness (WEF 2017)

\begin{tabular}{|l|l|l|}
\hline \multicolumn{3}{|l|}{ Table 3: ASEAN countries competitiveness } \\
\hline No. & Country & Index \\
\hline 1 & Singapore & 13 \\
\hline 2 & Malaysia & 26 \\
\hline 3 & Thailand & 34 \\
\hline 4 & Indonesia & 42 \\
\hline 5 & Vietnam & $\mathbf{6 7}$ \\
\hline 6 & Philippines & 79 \\
\hline 7 & Laos & 94 \\
\hline 8 & Cambodia & 101 \\
\hline
\end{tabular}

In comparison with other ASEAN countries in Travel and Tourism competitiveness in 2016, Vietnam is at the fifth rank after Singapore, Malaysia, Thailand, and Indonesia (Table 3). 


\begin{tabular}{|l|l|r|}
\hline \multicolumn{3}{|c|}{$\begin{array}{c}\text { Table 4: Human Resources } \\
\text { and labor market }\end{array}$} \\
\hline No. & Country & Score \\
\hline 1 & Singapore & 5.6 \\
\hline 2 & Malaysia & 5.2 \\
\hline 3 & Thailand & 4.9 \\
\hline 4 & Vietnam & $\mathbf{4 . 9}$ \\
\hline 5 & Philippines & 4.8 \\
\hline 6 & Indonesia & 4.6 \\
\hline 7 & Laos & 4.6 \\
\hline 8 & Cambodia & 4.1 \\
\hline
\end{tabular}

In terms of Human Resources and Labor Market, Vietnam is only behind Singapore, Malaysia and Thailand (Table 4); To other highly competitive factor as Natural resources, Vietnam ranks only after Thailand, Indonesia, and Malaysia (Table 5)

\begin{tabular}{|l|l|r|}
\hline \multicolumn{3}{|c|}{ Table 5: Natural Resources } \\
\hline No. & Country & Score \\
\hline 1 & Thailand & 4.9 \\
\hline 2 & Indonesia & 4.7 \\
\hline 3 & Malaysia & 4.1 \\
\hline 4 & Vietnam & $\mathbf{4}$ \\
\hline 5 & Philippines & 4 \\
\hline 6 & Cambodia & 3.2 \\
\hline 7 & Laos & 3 \\
\hline 8 & Singapore & 2.4 \\
\hline
\end{tabular}

For Cultural resources and Safety and Security, Vietnam is ranked the third, which are the most competitive strengths in the region. (Tables 6 and 7) In particular, the ICT readiness of Vietnam rose 17 positions compared to its index in 2016, ranking the $80^{\text {th }}$, after Singapore, Malaysia and Thailand. (Table 8)

\begin{tabular}{|l|l|r|}
\hline \multicolumn{3}{|c|}{ Table $6:$ Cultural resources } \\
\hline No. & \multicolumn{1}{|c|}{ Country } & Score \\
\hline 1 & Indonesia & 3.3 \\
\hline 2 & Singapore & 3.1 \\
\hline 3 & Vietnam & $\mathbf{3}$ \\
\hline 4 & Malaysia & 2.9 \\
\hline 5 & Thailand & 2.8 \\
\hline 6 & Philippines & 1.9 \\
\hline 7 & Cambodia & 1.6 \\
\hline 8 & Laos & 1.3 \\
\hline
\end{tabular}

\begin{tabular}{|l|l|r|}
\hline \multicolumn{3}{|c|}{ Table 7: Security and Safety } \\
\hline No. & Country & Score \\
\hline 1 & Singapore & 6.5 \\
\hline 2 & Malaysia & 5.8 \\
\hline 3 & Vietnam & $\mathbf{5 . 6}$ \\
\hline 4 & Laos & 5.4 \\
\hline 5 & Indonesia & 5.1 \\
\hline 6 & Cambodia & 5.1 \\
\hline 7 & Thailand & 4 \\
\hline 8 & Philippines & 3.6 \\
\hline
\end{tabular}

\begin{tabular}{|l|l|r|}
\hline \multicolumn{3}{|c|}{ Table 8: ICT Readiness } \\
\hline No. & Country & Score \\
\hline 1 & Singapore & 6.1 \\
\hline 2 & Malaysia & 5.2 \\
\hline 3 & Thailand & 4.8 \\
\hline 4 & Vietnam & $\mathbf{4 . 2}$ \\
\hline 5 & Philippines & 4 \\
\hline 6 & Indonesia & 3.8 \\
\hline 7 & Cambodia & 3.6 \\
\hline 8 & Laos & 3.1 \\
\hline
\end{tabular}

In general, ASEAN countries are facing with health and sanitation issues. Singapore and Malaysia are the leading ASEAN countries in this area. Vietnam ranks the third in eight countries (Table 9). The poor in Ground and air transport infrastructure will definitely affect the quality and capacity of the destination. The strong growth of tourism will lead to difficulties in the waste and wastewater treatment, causing the risk of environmental degradation, economic loss, and local people's life quality decrease. In Tables 10 and 11, Vietnam ranks the fifth out of eight countries examined.

\begin{tabular}{|c|c|c|c|c|c|}
\hline \multicolumn{3}{|c|}{ Table 9: Health and hygiene } & \multirow{2}{*}{\multicolumn{3}{|c|}{$\begin{array}{l}\text { Table 10: Land transport } \\
\text { Infrastructure }\end{array}$}} \\
\hline No. & Country & Score & & & \\
\hline 1 & Singapore & 5.5 & No. & Country & Score \\
\hline 2 & Malaysia & 5.2 & 1 & Singapore & 6.3 \\
\hline 3 & Vietnam & 5 & 2 & Malaysia & 4.4 \\
\hline 4 & Thailand & 49 & 3 & Indonesia & 3.2 \\
\hline 5 & $\because \cdot$ & & 4 & Thailand & 3.1 \\
\hline 5 & Philippines & 4.8 & 5 & Vietnam & 3.1 \\
\hline 6 & Indonesia & 4.3 & 6 & Philippines & 2.5 \\
\hline 7 & Lao & 4.3 & 7 & Lao & 2.4 \\
\hline 8 & Cambodia & 4 & 8 & Cambodia & 2.4 \\
\hline
\end{tabular}

Business environment is a concern for Vietnam, which is only at higher ranking than Cambodia and the Philippines. In addition, Vietnam's tourist service infrastructure is the lowest ranking in comparison to ASEAN countries. (Table 13) 


\begin{tabular}{|l|l|r|}
\hline \multicolumn{2}{|c|}{ Table 11: Air transport infrastructure } \\
\hline \multicolumn{1}{|c|}{ No. } & \multicolumn{1}{c|}{ Country } & \multicolumn{1}{c|}{ Score } \\
\hline 1 & Singapore & 5.3 \\
\hline 2 & Thailand & 4.6 \\
\hline 3 & Malaysia & 4.5 \\
\hline 4 & Indonesia & 3.8 \\
\hline 5 & Vietnam & $\mathbf{2 . 8}$ \\
\hline 6 & Philippines & 2.7 \\
\hline 7 & Lao & 2.1 \\
\hline 8 & Cambodia & 2.1 \\
\hline
\end{tabular}

\begin{tabular}{|l|l|r|}
\hline \multicolumn{3}{|c|}{ Table 12: Business Environment } \\
\hline No. & \multicolumn{1}{|c|}{ Score } & Country \\
\hline 1 & Singapore & 6.1 \\
\hline 2 & Malaysia & 5.4 \\
\hline 3 & Thailand & 4.7 \\
\hline 4 & Laos & 4.7 \\
\hline 5 & Indonesia & 4.5 \\
\hline 6 & Vietnam & 4.4 \\
\hline 7 & Philippines & 4.3 \\
\hline 8 & Cambodia & 3.7 \\
\hline
\end{tabular}

\begin{tabular}{|l|l|r|}
\hline \multicolumn{2}{|c|}{ Table 13: Tourism service infrastructure } \\
\hline No. & \multicolumn{1}{|c|}{ Score } & Country \\
\hline 1 & Thailand & 5.8 \\
\hline 2 & Singapore & 4.4 \\
\hline 3 & Malaysia & 3.5 \\
\hline 4 & Laos & 3.4 \\
\hline 5 & Phili ppines & 3.1 \\
\hline 6 & Indonesia & 2.9 \\
\hline 7 & Cambodia & 2.6 \\
\hline 8 & Vietnam & \\
\hline
\end{tabular}

\begin{tabular}{|l|l|r|}
\hline \multicolumn{2}{|c|}{ Table 14: UNESCO World Heritage Sites } \\
in ASEAN \\
\hline No. & Country & Number of Heritage \\
\hline 1 & Indonesia & 8 \\
\hline 2 & Vietnam & 8 \\
\hline 3 & Philippines & 6 \\
\hline 4 & Thailand & 5 \\
\hline 5 & Malaysia & 4 \\
\hline 6 & Laos & 2 \\
\hline 7 & Cambodia & 1 \\
\hline 8 & Singapore & 1 \\
\hline 9 & Myanmar & 0 \\
\hline 10 & Brunei & \\
\hline
\end{tabular}

\section{Vietnam tourism performance in relation to ASEAN countries in terms of important market segments (marine, urban, culture and eco-tourism)}

Tourism benefits from the natural and cultural destinations, including the World Heritage sites.

Indonesia and Vietnam are the two leading countries with the highest number of UNESCO World Heritage Sites in the 10 ASEAN countries. Indonesia has four cultural heritages, four natural heritages; Vietnam has five cultural heritages, two natural heritages and one mixed heritage; Thailand has three cultural heritages, two natural heritages. (Table 14)

ASEAN Marketing Strategy presents its focus which includes comprehensive themes and is relevant to the global trend, namely, gastronomy, health care, culture and heritage; and natural and adventure (ASEAN Secretariat, 2017, p. 12). In 2017, the total revenue generated from tourism in Vietnam is 541,000 billion VND (23 billion USD), in which the most tourists' expenditure is on food and beverage and accommodation, and transportation, followed by other expenses such as shopping, sightseeing, and others (Figure 3). 


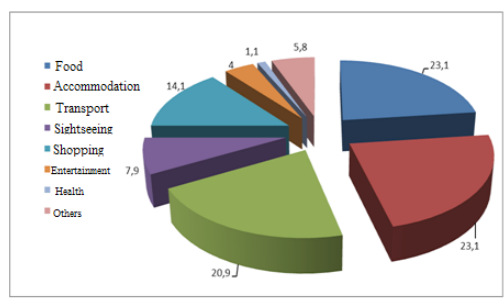

Figure 3: Shares of total tourism revenue in 2017 (Source: VNAT)

In the past four years, Thailand witnesses the most impressive growth in terms of international visitors, which surpassed Malaysia by 2015 and 2016 with the annual increases of $20.6 \%$ and $8.9 \%$ respectively. In particular, although Thailand is not completely in outstanding role to Malaysia in terms of arrivals, it generated higher revenue compared to Malaysia and Singapore, being the regional leading destination with nearly 45 billion USD in 2015 and 50 billion USD in 2016. Though Vietnam ranked at the $4^{\text {th }}$ position in terms of tourist arrivals, it takes the $5^{\text {th }}$ position on the revenue list and only covers $16.54 \%$ in comparison with Thailand in 2016. In the period of 2014-2016, Thailand accounts for major share of visitors of $23.6 \%$, $27.45 \%$ and $28.10 \%$ respectively compared to the region. The average rate of 3 years is $26.38 \%$. At the same time, the number of international visitors to Vietnam in ASEAN was $7.58 \%, 7.29 \%$ and $8.63 \%$ respectively. The 3-year average is $7.83 \%$, which covers $29.7 \%$ to Thailand's (Table 12,13 ).

\begin{tabular}{|l|c|c|c|c|c|c|c|c|c|}
\hline \multirow{3}{*}{ No } & \multirow{6}{*}{ Country } & \multicolumn{6}{|c}{ Table 15: International tourist arrivals to ASEAN countries } \\
\cline { 3 - 9 } & & $\mathbf{2 0 1 0}$ & $\mathbf{2 0 1 4}$ & $\mathbf{2 0 1 5}$ & $\mathbf{2 0 1 6}$ & \multirow{3}{*}{ Shares in ASEAN (\%) } \\
\hline & ASEAN & $\mathbf{7 3 , 8 0 0}$ & 105,000 & 108,900 & 116,000 & $\mathbf{2 0 1 5}$ & $\mathbf{2 0 1 6}$ & 3-year average \\
\hline $\mathbf{1}$ & Thailand & 15,936 & 24,810 & 29,923 & 32,588 & 23.63 & 27.48 & 28.09 & 25.55 \\
\hline $\mathbf{2}$ & Malaysia & 24,577 & 27,437 & 25,721 & 26,757 & 26.13 & 23.62 & 23.07 & 24.87 \\
\hline $\mathbf{3}$ & Singapore & 9,161 & 11,864 & 12,052 & 12,913 & 11.30 & 11.07 & 11.13 & 11.18 \\
\hline $\mathbf{4}$ & Indonesia & 7,003 & 9,435 & 9,963 & 11,520 & 8.99 & 9.15 & 9.93 & 9.07 \\
\hline $\mathbf{5}$ & Vietnam & $\mathbf{5 , 0 5 0}$ & $\mathbf{7 , 9 6 0}$ & $\mathbf{7 , 9 4 4}$ & $\mathbf{1 0 , 0 1 3}$ & $\mathbf{7 . 5 8}$ & $\mathbf{7 . 2 9}$ & $\mathbf{8 . 6 3}$ & $\mathbf{7 . 4 4}$ \\
\hline $\mathbf{6}$ & Philippines & 3,520 & 4,833 & 5,361 & 5,967 & 4.60 & 4.92 & 5.14 & 4.76 \\
\hline $\mathbf{7}$ & Cambodia & 2,508 & 4,503 & 4,775 & 5,012 & 4.29 & 4.38 & 4.32 & 4.34 \\
\hline $\mathbf{8}$ & Myanmar & 792 & 3,081 & 4,681 & 2,91 & 2.93 & 4.30 & 2.51 & 3.62 \\
\hline $\mathbf{9}$ & Laos & 1,670 & 3,164 & 3,543 & 3,315 & 3.01 & 3.25 & 2.86 & 3.13 \\
\hline $\mathbf{1 0}$ & Brunei & 214 & 201 & 218 & 219 & 0.19 & 0.20 & 0.19 & 0.20 \\
\hline
\end{tabular}

\begin{tabular}{|l|l|c|c|c|c|c|}
\hline \multirow{2}{*}{ No. } & \multirow{2}{*}{ Country } & \multicolumn{4}{|c|}{ Table 16: International tourism revenue by ASEAN countries (million USD) } \\
\cline { 3 - 7 } & & $\mathbf{2 0 1 0}$ & $\mathbf{2 0 1 4}$ & $\mathbf{2 0 1 5}$ & $\mathbf{2 0 1 6}$ & 3-consecutive year average \\
\hline 1 & Thailand & 20.104 & 38.418 & 44.922 & 49.871 & 44.404 \\
\hline 2 & Singapore & 14.178 & 19.134 & 16.563 & 18.386 & 18.028 \\
\hline 3 & Malaysia & 18.115 & 22.595 & 17.584 & 18.074 & 19.418 \\
\hline 4 & Indonesia & 6.958 & 10.261 & 10.761 & 11.349 & 10.790 \\
\hline 5 & Vietnam & $\mathbf{4 . 4 5 0}$ & $\mathbf{7 . 4 1 0}$ & $\mathbf{7 . 3 5 0}$ & $\mathbf{8 . 2 5 0}$ & $\mathbf{7 . 6 7 0}$ \\
\hline 6 & Philippines & 2.645 & 5.030 & 5.272 & 5.139 & 5.147 \\
\hline 7 & Cambodia & 1.519 & 2,953 & 3,130 & 3,207 & 3,097 \\
\hline 8 & Myanmar & 72 & 1,613 & 2,101 & 2,177 & 1,964 \\
\hline 9 & Laos & 382 & 642 & 581 & 540 & 588 \\
\hline 10 & Brunei & --- & 79 & 140 & --- & 110 \\
\hline
\end{tabular}


To most countries in ASEAN, tourism is one of the main on-spot export sectors and the main source of foreign currencies. Cambodia is a leading country which generates highincome from international tourists, accounting for $29 \%$ of the total national export income value in GDP. The total contribution of tourism in GDP of Indonesia is $6.2 \%$.

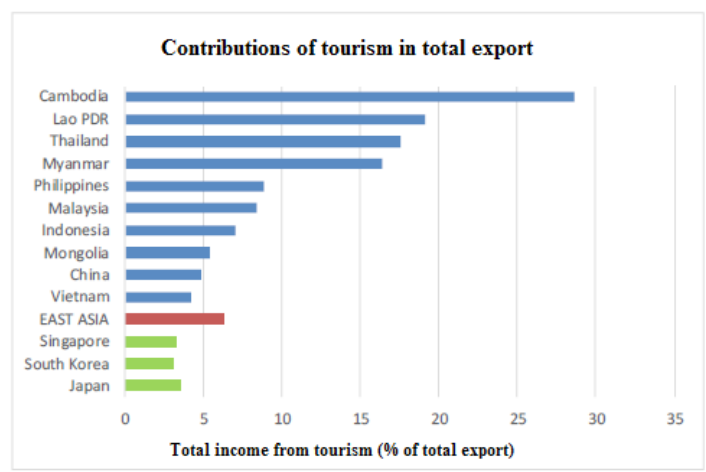

Source: World Development Index (WDI) 2017

\section{Observations}

Based on the above analysis of tourism competitiveness and performance, the observations are made as follows.

Although Cambodia, Myanmar, and Laos achieved the average growth rate of $4.3 \%, 3.6 \%$ and $3.1 \%$ in terms of international visitors for three years inclusively, the number still accounts for only a small fraction in the region. The Philippines and Indonesia are the two closest competitors to Vietnam with strong growth both in terms of volume and revenue. Though the Philippines is currently ranked below Vietnam, the potential, opportunities and the diversity of tourism development and products are not less competitive. According to the World Bank updates on tourism development in developing countries in East Asia, in Vietnam, the number of domestic tourists is four to nine times higher than that of international visitors. Nevertheless, this number is 25 times in Indonesia, and 50 times in the Philippines (World Bank Group, 2017, p. 89). Though Vietnam witnessed positive growth in tourist arrivals in the past two years, it is still behind other tourism developed countries in the region such as Thailand, Malaysia and Singapore in terms of the absolute numbers of visitors and revenue. Indonesia has a slightly higher number of tourist arrivals than Vietnam, but its revenue is considerably higher than Vietnam.

The issues that Vietnam tourism is facing in the situation of rapid tourism growth is the infrastructure and tourism facilities, as it has to ensure sustainable development when Vietnam ranked the $8^{\text {th }}$ out of eight countries reviewed in tourism infrastructure (WEF). In addition, the ground and air transport infrastructure of Vietnam is also a constraint, requiring a master plan and close coordination between the tourism and the transport sector. The issue of business and institutional environment which facilitates businesses is still a gap that Vietnam needs to fill in.

In conclusion, many of the advantages of Vietnam tourism are highlighted by international organizations in ASEAN such as natural and cultural resources, ICT readiness, human resources and labor market for tourism development. In order to maintain the growth momentum and enhance the position of tourism in the ASEAN region, Vietnam needs to give prioritization to the satisfaction of the needs of the key markets, overcome weaknesses in infrastructure and favorable policies for businesses, improve environmental quality standards, ecofriendly tourism products, and enhance the participation of local communities in tourism. 


\section{Recommendations}

Vietnam witnesses the encouraging increase of international arrivals in recent years and enjoys economic benefits from this booming tourism activity. However, the tourism quality must be shifted rather than the quantity of tourism, and the sector development should be strengthened in a more environmentally, culturally, and socially sustainable manner. Therefore, some recommendations which are based on the above observations are as follows:

- Diversification of products and marketing strategies: Product development and diversification should focus on eco-friendly tourism offerings and be increasingly targeted at higher-spending visitor source markets.

- Strengthening tourism human resources and local economy linkages: The supply of skilled tourism labor should be grown faster to keep up with accelerating demand. The sufficient quantity of local workers should be in line with the various goods and services offered as the two sides of a coin.

- Improvement of tourism infrastructure: The quality of tourism infrastructure must meet higher standards in line with the orientation of developing more eco-friendly tourism products.

- Tourism destination management: Strategic coordination of destination planning and product development should be highlighted.
If we have proper and strategic view on development oritentation, avoiding mass tourism, and follow the trend of maintaining environmental, cultural, and social sustainability, the results will be invaluable as it ensures the right measures, effective monitoring and evaluation, and sustainable economic growth for decades to come.

\section{References}

ASEAN Secretariat, (2017), ASEAN Tourism Marketing Strategy (ATMS) 2017-2020, p.12. Jakarta: The ASEAN Secretariat.

Asian Development Bank, (2017), Asian Development Outlook 2017, p. 69. Manila: Asian Development Bank.

Crotti, R., \& Misrahi, T. (2017), The Travel \& Tourism Competitiveness Report 2017, p.15. Geneva: World Economic Forum

Manzo, G., (2018), Travel \& Tourism Economic Impact: World, p.2. London: World Travel \& Tourism Council

World Bank, (2017), East Asia and Pacific Economic Update, October 2017 - Balancing Act, p. 89. Washington, D.C.: World Bank Group

World Bank, ITDR, (2018), Vietnam Tourism Sector Analysis, p.2. Hanoi: World Bank - Institute for Development Research

World Tourism Organization, (2011), Towards Tourism 2030/ Global Overview, p.34. Madrid: World Tourism Organization

World Tourism Organization, (2017), UNWTO Tourism Highlights: 2017 Edition, p. 9. Madrid: World Tourism Organization

World Tourism Organization, (2018), UNWTO Tourism Highlights: 2018 Edition, p.5. Madrid: World Tourism Organization 


\title{
PHÂN TÍCH NĂNG LỰC CẠNH TRANH CỦA DU LỊCH VIỆT NAM TRONG MỐI LIỀN HỆ VỚI CÁC QUỐC GIA ASEAN HIỆN NAY
}

\author{
Vũ Chiến Thắng \\ Phòng Quản lý khoa học và Hợp tác quốc tế, Viện Nghiên cứu Phát triển Du lịch, \\ 58 Kim Mã, Ba Đình, Hà Nội, Việt Nam
}

Tóm tắt: Bài báo này phân tích các khía cạnh ảnh hưởng tới năng lực cạnh tranh của du lịch Việt Nam trong mối liên hệ với các quốc gia Đông Nam Á (ASEAN). Các vấn đề được đề cập bao gồm: (1) thị phần khách du lịch quốc tế của Việt Nam trong ASEAN; (2) Thứ bậc của Việt Nam trong bảng xếp hạng năng lực cạnh tranh của Diễn đàn Kinh tế Thế giới (WEF); (3) Hiệu quả của du lịch Việt Nam trong mối tương quan với các quốc gia ASEAN.

Tù khóa: du lịch ASEAN, du lịch Việt Nam, năng lực cạnh tranh 